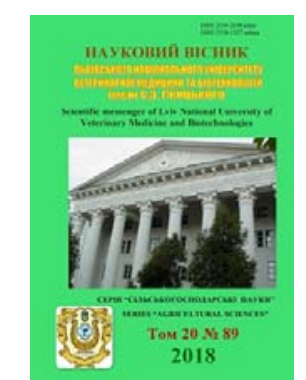

Науковий вісник Дьвівського національного університету ветеринарної медицини та біотехнологій імені С.3. Гжицького

\author{
Scientific Messenger of Lviv National University \\ of Veterinary Medicine and Biotechnologies
}

\title{
Productive effect of different amounts of triticale grain on reproductive parameters of the rabbits and quality of the offspring
}

\author{
H.M. Sedilo ${ }^{1}$, I.S. Luchyn ${ }^{1}$, M.V. Hryniv ${ }^{1}$, L.M. Darmohray ${ }^{2}$, J.I. Pivtorak ${ }^{2}$, B.V. Gutyj ${ }^{2}$ \\ ${ }^{1}$ Institute of Agriculture of Carpathian Region of Ukraine NAAS, Obroshino, Ukraine \\ ${ }^{2}$ Stepan Gzhytskyi National University of Veterinary Medicine and Biotechnologies Lviv, Ukraine
}

Article info

Received 06.09.2018

Received in revised form 08.10 .2018

Accepted 09.10.2018

Institute of Agriculture of Carpathian region of

Ukraine, NAAS of Ukraine, Grushevskogo Str., 5, Obroshino, 81115, Ukraine.

Stepan Gzhytskyi National University of Veterinary Medicine and Biotechnologies Lviv, Pekarska Str., 50, Lviv, 79010, Ukraine.

Tel.: +38-097-561-52-30 E-mail:murolyb@ukr.net
Sedilo, H.M., Luchyn, I.S., Hryniv, M.V., Darmohray, L.M., Pivtorak, J.I. \& Gutyj, B.V. (2018). Productive effect of different amounts of triticale grain on reproductive parameters of the rabbits and quality of the offspring. Scientific Messenger of Lviv National University of Veterinary Medicine and Biotechnologies, 20(89), 61-66. doi: 10.32718/nvlvet8911

According to the experiment, the productive effect of different amounts of grain of the triticale of Harroz variety in feed for the reproductive indices of feeding rabbits was established. According to the tasks assigned, five groups of nursing rabbits were selected and formed according to the principle of analogues. To feed the experimental nursing rabbits, a full granulated mixed feed was used in the structure of which there was a different content of triticale grain: II research group - 10.0\%, III, IV and V research groups $20.0 \%, 30.0 \%$ and $40.0 \%$ respectively. Nursing rabbits of the 1 st control group were fed full-fat mixed fodders, which were balanced for the main nutrients, but did not contain triticale grain. In the study of the multiplicity of feeding rabbits with different contents of crushed grain of the triticale of the Harroz variety, it was higher in the $3 r d$ and 4th experimental groups (in the ration of 20 and $30 \%$ of the crushed grain of triticale) with an index of 8.0-8.2 heads $(P<0.05)$. The large-fruited index predominated in the nursing rabbits of the 4th experimental group and amounted to $65 \mathrm{~g}$; in the $1 \mathrm{st}, 2 \mathrm{nd}$, 3rd and 5 th groups it was 62, 63, 64, and 61g. The amount of milk of nursing rabbits is an indicator that positively correlates with fecundity, the weight of rabbits at birth (large-fruited), the preservation of the nest. Milk index was also the best in nursing rabbits of the 4th group and amounted to $2.83 \mathrm{~kg}$, which is $0.09-0.24 \mathrm{~kg}$ more than in all other groups $(P<0.01)$. By the number of rabbits with weaning at 35 days, the fourth group of nursing rabbits predominated, this index was $7.1 \mathrm{~g}$. The average live weight of one head during separation was higher by $40-50 \mathrm{~g}$ in the $3 \mathrm{rd}$ and 4 th test groups compared to the first control group and amounted to 0.75 and 0.76 $\mathrm{kg}(P<0.05)$. According to preliminary indications, the best nest weight in weaning during 35 days was the nursing rabbits of the 4 th group $-5.36 \mathrm{~kg}$, which is $0.47 \mathrm{~kg}$ higher than the control $(P<0.05)$. The highest percentage of conservation of rabbits before weaning at 35-day-old age was observed in groups 3, 4 and 5, and was at the level of 94.59; 93.42; 97.1\%. It was found that the structure of the ration of nursing rabbits with a content of crushed grain of triticale of Harroz 20, 30 and 40\% was significantly influenced the preservation of the nest. The index - the index of the reproductive qualities of feeding rabbits (IVKK), based on the indicators of large-fruited, milk and number of rabbits with weaning (35 days) was higher in feeding rabbits of $3 \mathrm{rd}$ and 4th groups and amounted to 126.4 and 128.8. The maximum reproductive indices of feeding rabbits provided a structural content in the diet of $30 \%$ of the crushed grain of the triticale of the Harroz variety (the fourth research group). The ration (30\% of the triticale crushed grain) ensured the growth of the multiplicity by $8.5 \%$, the size of the fetus by $5 \%$, the milkness of the rabbits by $9 \%$, the weight of the nest at weaning at 35 days old by $9.6 \%$, and the complex index of IVKK by $6.5 \%$.

Key words: rabbits, structure of the diet, triticale digestion, reproductive indexes, intensive production.

\section{Продуктивна дія різної кількості зерна тритікале на репродуктивні показники кролематок та якість приплоду}

\author{
Г.М. Седіло ${ }^{1}$, І.С. Лучин ${ }^{1}$, М.В. Гринів ${ }^{1}$, Л.М. Дармограй${ }^{2}$ Я.І. Півторак ${ }^{2}$, Б.В. Гутий${ }^{2}$ \\ ${ }^{1}$ Інститут сільського господарства Карпатського регіону Украӥни НААН, с. Оброшино, Украӥна \\ ${ }^{2}$ Львівський національний університет ветеринарної медицини та біотехнологій імені С. 3. Гюицького, \\ м. Львів, Україна
}


Згідно проведеного експерименту встановлено продуктивну дію різної кількості зерна тритікале сорту Харроза у комбікормі на репродуктивні показники кролематок. Згідно поставлених завдань було підібрано і сформовано п'ять груп кролематок за принципом аналогів. Для годівлі піддослідних кролематок використовували повнораціонний гранульований комбікорм у структурі якого був різний вміст зерна тритікале: II дослідна група - 10,0\%, III, IV та V дослідні групи - 20,0\%, 30,0\% та 40,0\% відповідно. Піддослідним кролематкам I контрольної групи згодовували повнорачіонний комбікорм, який був збалансований за основними поживними речовинами, але не містив зерна тритікале. Після дослідження багатоплідності кролематок за різного вмісту дерті зерна тритикале сорту Харроза вона виявилась вищою у 3 i 4-ї дослідних групах (в раціоні 20 і 30\% дерті тритикале) з показником 8,08,2 тварин (P < 0,05). Показник великоплідності переважав у кролематок 4-ї дослідної групи і становив 65 г, в 1; 2 , 3 i 5-ї груп він становив 62, 63, 64 і 61 г. Молочність кролематок- -е показник, який позитивно корелює з плодючістю, масою кроленят при народженні (великоплідність), збереженістю гнізда. Показник молочності також був кращим у кролематок 4-ї групи та становив 2,83 кг, ше на 0,09-0,24 кг більше ніж у всіх інших групах $(P<0,01)$. За кількістю кроленят після відлучення в 35 діб переважала 4-а група кролематок, цей показник становив 7,1 гол. Середня жива маса однієї голови після відлучення була вищою на 40-50 г в 3 i 4-й дослідних групах в порівнянні до першої контрольної і становила 0,75 i 0,76 кг $(P<0,05)$. Згідно попередніх показників кращиими за масою гнізда при відлученні в 35 діб були кролематки 4-ї групи - 5,36 кг, щуо на 0,47 кг вище контрольної групи (Р < 0,05). Найвищий відсоток збереження кроленят до відлучення в 35-добовому віці спостерігався в групах 3, 4 та 5-й $i$ знаходився на рівні 94,59; 93,42; 97,1\%. Встановлено, шуо на збереження гнізда значною мірою вплинула структура раціону кролематок з вмістом дерті зерна тритікале сорту Харроза 20, 30 і 40\%. Показник - індекс відтворювальних якостей кролематок (ІВЯк) виходячи з показників великоплідності, молочності і кількості кроленят при відлученні (в 35 діб) вищим був у кролематок 3 і 4-ї груп і становив 126,4 та 128,8. Максимальні репродуктивні показники кролематок забезпечив структурний вміст в раціоні 30\% дерті зерна тритикале сорту Харроза (4-а дослідна група). Раціон (30\% дерті зерна тритикале) забезпечив зростання багатоплідності на 8,5\%, великоплідності на 5\%, молочності кролематок на 9\%, маси гнізда після відлучення в 35-добовому віці на 9,6\%, а комплексного індексу ІВЯК на 6,5\%. Окреслено перспективи подальших наукових досліджень щуодо вивчення трансформації даного корму при тривалому згодовуванні за умови промислового вирощування кролів.

Ключові слова: кролематки, структура раціону, дерть тритікале, репродуктивні показники, інтенсивне виробництво.

\section{Вступ}

Відтворення сільськогосподарських тварин є важливим біологічним процесом, який залежить від спадкових особливостей та умов і характеру годівлі. Ефективність функцій відтворної здатності тварин на 10-20\% залежить від генотипу, а 80-90\% визначається паратиповими факторами i в першу чергу годівлею (Darmohray, 2010; Gutyj et al., 2017; Darmohray et al., 2017).

В умовах ринкової економіки цей показник має вирішальне значення для рентабельності господарств - виробників та конкурентоспроможності виробленої продукції. На ринку кормів скорочується частка кормових компонентів тваринного походження, 3'являються нові нетрадиційні корми, а також кормові добавки, призначені для покращення засвоєння поживних речовин.

Репродуктивні якості кролематок, а також розвиток кроленят у натальний період і життєздатність їх у постнатальний період значною мірою обумовленні типом годівлі, рівнем протеїну та структурою раціону (Luchyn, 2004). Сьогодні залишаються надзвичайно актуальними питання розроблення нових способів використання кормів та створення нових, пристосованих до конкретних технологій утримання та годівлі (Darmohray and Luchyn, 2016). Актуальним є дослідження, пов'язані із встановленням продуктивної дії кормових засобів, особливо малопоширених, на процеси метаболізму i продуктивність тварин (Darmohray et al., 2017).

Розвиток кролівництва, як спеціалізованої галузі потребує всебічного оцінювання їх кормової бази (Luchyn et al., 2016). Зокрема, необхідно вивчати продуктивну дію кожного корму і раціону в цілому на обмін речовин, відтворну здатність, якість продукції, функціонування організму кролів (Darmohray and Shevchenko, 2016).
Для здешевлення виробництва кролятини доцільно використовувати нетрадиційні корми, як при змішаному, так і при сухому типах годівлі (Romanov, 2009; Darmohray and Luchyn, 2016). Однак при сухому типі годівлі затрати кормів на одиницю приросту нижчі на $20,2 \%$, загальні затрати - на 10,8\%, а інтенсивність росту вища на 5,2\%, рентабельність виробництва - на 14\% (Symonov and Hurevych, 2012).

Одним із резервів поповнення кормової бази зернових $є$ використання тритікале. Тритікале - зернова культура, виведена схрещуванням пшениці з житом. Характеризується потенційною врожайністю, високим умістом у зерні білка і незамінних амінокислот (лізину, триптофану) (Izmestev et al., 2011).

Тритікале містить багато протеїну, лізину та триптофану, добре поєднується в комбікормах з ячменем. Слід враховувати, що тритікале містить антипоживні речовини (алкілрезорцини), а також багато незамінних амінокислот.

Інші дослідники вважають, що зерно тритікале слід включати в комбікорми для молодняку свиней до $50 \%$ до маси ячменю. Повна заміна ним ячменю справляє негативний вплив на ріст і розвиток тварин. Включення підвищеної кількості тритікале вимагає подальшого балансування поживних речовин відповідно до деталізованих норм годівлі відгодівельного молодняку свиней (Holushko and Marusevych, 1996; Horkovenko et al., 2010).

Згодовування зерна тритікале взамін 10-15\% ячменю курчатам-бройлерам покращує збереження поголів'я на 1,6-8,3\%. Витрати корму на 1 кг приросту зменшуються при згодовуванні тритікале від 4,4 до 9,3\% (Tletseruk, 2010).

У кролівництві немає достатньо досліджень 3 використання зерна тритікале в годівлі кролів і тим більше нового сорту Харроза.

Новий сорт Харроза рекомендований для вирощування в зонах Лісостепу і Полісся, створений методом індивідуального добору з гібридної популяції від 
схрещування ярого сорту Сокіл харківський і озимого Амфідиплоїд 52 з наступним об'єднанням морфологічно близьких ліній.

Наукові дослідження $з$ даної теми істотно підвищать економічну ефективність інтенсивного виробництва кролятини в Прикарпатті шляхом фізіологічної оптимізації раціону помісних кролематок i низької ціни фуражного зерна тритікале сорту Харро3a.

Актуальність. Для забезпечення економічної ефективності за умов інтенсивного виробництва кролятини, доцільна фізіологічна i економічна оптимізація раціону кролематок, за показниками: вмісту сирого протеїну, амінокислот, сирої клітковини; при оптимальному використанні місцевих конкурентоздатних кормових інгредієнтів.

Мета досліджень - удосконалення рецептів повнораціонних гранульованих комбікормів для кролематок 3 оптимальним вмістом зерна сорту тритікале Харроза та преміксів до них за умов інтенсивного виробництва.

\section{Матеріал і методи досліджень}

Дослідження проводились у Прикарпатській державній сільськогосподарській дослідній станції. В господарстві застосовуються основні елементи інтенсивної технології. Генотип кролематок, що використовувався в дослідженні - трьохпородні помісі білого велетня, шиншили та фландра (НТШ).

Основні елементи технології, що наявні в дослідженні:

- 7-8 окролів у рік від основної кролематки;

- максимальне сумісництво сукрільності і лактації;

- відлучення кроленят на 35 добу життя;

- збереженість гнізда до відлучення 90\%;

Для досліду, методом пар-аналогів, було сформовано 5 груп сукрільних кролематок по 10 голів в кожній.

Оцінка фізіологічного стану сукрільних кролематок визначалась шляхом зважування кролематок на п’яту і останню добу сукрільності.

Рецепти комбікормів у дослідженнях розраховані згідно європейських норм для кролематок за інтенсивного виробництва кролятини (Maertes et al., 2002) та за наявних в регіоні кормових компонентів і в тому числі дерті зерна тритікале сорту Харроза. Дерть тритікале в дослідженнях пропорційно замінювали зерном пшениці і частково зерном ячменю.

Схема досліджень та рецепти комбікормів наведені в таблицях 1 і 2.

\section{Таблиця 1}

Схема досліду

\begin{tabular}{cll}
\hline \multirow{2}{*}{ Група } & \multicolumn{1}{c}{ Кролематки - трьохпородні помісі (НТШ), характер годівлі, $\mathrm{n}=10$} \\
\cline { 2 - 3 } & \multicolumn{1}{c}{ Підготовчий період, 5 діб } & \multicolumn{1}{c}{ Основний період, 60 діб } \\
\hline I(контрольна) & Визначення оптимального & О. Р. - Повнораціонний гранульований комбікорм \\
II (дослідна) & вмісту дерті зерна тритікале & О. Р. + ОКФ 10\% дерті зерна тритікале сорту Харроза \\
III(дослідна) & сорту Харроза в раціоні помі- & О. Р. + ОКФ 20\% дерті зерна тритікале сорту Харроза \\
IV(дослідна) & сних кролематок & О. Р. + ОКФ 30\% дерті зерна тритікале сорту Харроза \\
V(дослідна) & & О. Р. + ОКФ 40\% дерті зерна тритікале сорту Харроза \\
\hline
\end{tabular}

\section{Таблиця 2}

Структура і поживність комбікормів для піддослідних кролематок

\begin{tabular}{|c|c|c|c|c|c|c|}
\hline \multirow{3}{*}{ №/n } & \multirow{3}{*}{$\begin{array}{c}\text { Кормові } \\
\text { компоненти }\end{array}$} & \multicolumn{5}{|c|}{ Рецепти № } \\
\hline & & 1 & 2 & 3 & 4 & 5 \\
\hline & & контроль & дослід & дослід & дослід & дослід \\
\hline 1 & Дерть ячменю & 25,65 & 25,65 & 25,65 & 15,65 & 5,65 \\
\hline 2 & Дерть пшениці & 20,00 & 10,00 & - & - & - \\
\hline 3 & Дерть тритікале & - & 10 & 20 & 30 & 40 \\
\hline 4 & Шроти соняшнику 38 \% & 20,00 & 20,00 & 20,00 & 20,00 & 20,00 \\
\hline 5 & Трав'яне борошно & 30,00 & 30,00 & 30,00 & 30,00 & 30,00 \\
\hline 6 & Сіль кухонна & 0,45 & 0,45 & 0,45 & 0,45 & 0,45 \\
\hline 7 & Премікс & 3,9 & 3,9 & 3,9 & 3,9 & 3,9 \\
\hline 8 & Разом, \% & 100 & 100 & 100 & 100 & 100 \\
\hline 9 & Міститься в 1 кг комбікормі: & & & & & \\
\hline 10 & Сухої речовини, кг & 0,840 & 0,840 & 0,840 & 0,840 & 0,840 \\
\hline 11 & Обмінної енергії, МДж & 7,73 & 7,71 & 7,68 & 7,67 & 7,66 \\
\hline 12 & Сирого протеїну, г & 172,58 & 173,28 & 173,98 & 176,68 & 179,38 \\
\hline 13 & Сирої клітковини, г & 129 & 130 & 130 & 128 & 126 \\
\hline 14 & Вартість 1 кг комбік., грн. & 4,65 & 4,55 & 4,45 & 4,35 & 4,25 \\
\hline 15 & Вартість 1 т комбік., грн. & 4654 & 4554 & 4454 & 4354 & 4254 \\
\hline
\end{tabular}


У склад повнораціонних гранульованих комбікормів входили такі кормові інгредієнти: дерть ячмінна, дерть пшенична, дерть зерна тритікале Харроза, шрот соняшнику $38 \%$, трав'яне борошно, $4 \%$ премікс.

Критерій оцінки кролематок: плодючість, великоплідність, молочність (жива маса кроленят в 20добовому віці), показники гнізда в 35-добовому віці, визначення ІВЯК.

Для визначення об'єктивної оцінки продуктивності кролематки використовуємо індекс (ІВЯК) (Luchyn and Vakulenko, 2004):

$$
\mathrm{I}=\mathrm{B}+10 \mathrm{~m}+5 \mathrm{Z}
$$

де: В - середня маса одного кроленяти після народження в грамах;

m - молочність кролематки в кілограмах;

Z - кількість кроленят при відлученні в 35добовому віці.

10,5 - поправочні коефіцієнти.

Біометричну обробку цифрових даних здійснювали за допомогою програмного забезпечення MS Excel 3 використанням вбудованих статистичних функцій. Вірогідним вважали показник при значенні * $-\mathrm{P}<$ 0,$05 ; * *-\mathrm{P}<0,01 ; * * *-\mathrm{P}<0,001$ порівняно до контролю.

\section{Результати та їх обговорення}

При постановці на дослід сукрільних кролематок, розбіжність за віком становила не більше 15 діб, у живій масі однієї голови в середньому по групі до 50 г (табл. 3).

Кролематки були спаровані протягом 10 діб. Жива маса кролематок на 30 добу сукрільності за групами була дещо різною. Максимально переважала 4-а дослідна група кролематок, що в середньому на 160г більше порівняно до першої контрольної. Кролемат- кам четвертої групи згодовували раціоні з вмістом зерна тритікале на рівні $30 \%$.

\section{Таблиця 3}

Жива маса кролематок після постановки на дослід, $\mathrm{M} \pm \mathrm{m}, \mathrm{n}=50$

\begin{tabular}{lcc}
\hline \multirow{2}{*}{ Група } & \multicolumn{2}{c}{ Період зважування, жива маса, кг } \\
\cline { 2 - 3 } & $\begin{array}{c}5 \text { доба після } \\
\text { осіменіння }\end{array}$ & $\begin{array}{c}30 \text { доба } \\
\text { сукрільності }\end{array}$ \\
\hline I контрольна & $3,92 \pm 0,112$ & $4,34 \pm 0,037$ \\
II дослідна & $3,93 \pm 0,111$ & $4,40 \pm 0,032$ \\
III дослідна & $3,91 \pm 0,115$ & $4,43 \pm 0,038$ \\
IVдослідна & $3,96 \pm 0,115$ & $4,50 \pm 0,048$ \\
Удослідна & $3,94 \pm 0,114$ & $4,33 \pm 0,029$ \\
\hline
\end{tabular}

У таблиці 4 наведені репродуктивні показники кролематок трьохпородного генотипу за період досліду. Структурний вмістом дерті зерна тритікале сорту Харроза був відповідно схеми досліджень $(0,10,20$, 30 i $40 \%)$.

Дослідженням багатоплідності кролематок, за різного вмісту дерті зерна тритікале сорту Харроза, встановлено, що у 3 і 4-й дослідних групах вона була 3 показником 8,0-8,2 тварин. За цим показником самки четвертої групи вірогідно переважали кролематок контрольної групи на 9,3\% (P < 0,05).

Великоплідність значною мірою впливає на загальну оцінку кролематок та подальшу відгодівельну продуктивність одержаного молодняку кролів. Показник великоплідності переважав у кролематок 4-ї дослідної групи і становив 64,7 г, а у 1; 2, 3 і 5-й групі він становив $61,8,62,8$ і 61 г відповідно. Із зростанням великоплідності покращувалась молочність кролематок та збереженість підсисних кроленят по групах.

Таблиця 4

Репродуктивні показники кролематок за період досліду, $\mathrm{M} \pm \mathrm{m}, \mathrm{n}=50$

\begin{tabular}{|c|c|c|c|c|}
\hline Групи & $\begin{array}{c}\text { Багатоплідність, } \\
\text { тварин }\end{array}$ & $\begin{array}{c}\text { В тому числі } \\
\text { мертвонароджених, } \\
\text { тварин } \\
\end{array}$ & $\begin{array}{c}\text { Великоплідність, } \\
\text { г } \\
\end{array}$ & $\begin{array}{c}\text { Молочність, } \\
\text { кг }\end{array}$ \\
\hline І к & $7,5 \pm 0,373$ & $0,4 \pm 0,163$ & $61,8 \pm 2,07$ & $2,59 \pm 0,072$ \\
\hline II & $7,9 \pm 0,433$ & $0,6 \pm 0,163$ & $62,8 \pm 3,004$ & $2,67 \pm 0,073$ \\
\hline III & $8,0 \pm 0,394$ & $0,6 \pm 0,221$ & $63,8 \pm 2,065$ & $2,74 \pm 0,08^{*}$ \\
\hline IV & $8,2 \pm 0,467^{*}$ & $0,6 \pm 0,221$ & $64,7 \pm 2,959$ & $2,83 \pm 0,052 * *$ \\
\hline $\mathrm{V}$ & $7,6 \pm 0,452$ & $0,7 \pm 0,26$ & $61,0 \pm 2,44$ & $2,62 \pm 0,082$ \\
\hline
\end{tabular}

Показник мертвонароджених кроленят незначно різниться по групах і вірогідної різниці немає $(0,4-$ 0,7 гол). Проте є деяка тенденція до зниження цього показника 3 вмістом у раціонах кролематок 40\% дерті зерна тритікале сорту Харроза.

Молочність кролематок - це показник, який позитивно корелює 3 плодючістю, масою кроленят після народження (великоплідність), збереженістю гнізда. Показник молочності також був кращим у кролематок 4-ї групи та становив 2,83 кг, що на 0,09-0,24 кг біль- ше ніж у всіх інших груп. Вірогідною $є$ різниця за показниками молочності між кролематками 3 i 4-ої дослідних груп порівняно 3 контрольною групою $(\mathrm{P}<0,05 ; \mathrm{P}<0,01)$.

Показники збереженості кроленят та якість приплоду за період досліду наведено у таблиці 5. Дані таблиці 5 вказують, що за кількістю кроленят при відлученні переважала 4-а група, цей показник становив 7,1 голову, відсоток дерті тритікале в структурі раціону кролематок становив $30 \%$. 
Таблищя 5

Якісні показники приплоду за відлучення кроленят у 35 -добовому віці ( $\mathrm{M} \pm \mathrm{m}, \mathrm{n}=50)$

\begin{tabular}{cccccc}
\hline Групи & Кількість, тварин & Сер. ж. м. 1 тварини, кг & Маса гнізда, кг & Збереження, \% & ІВЯК \\
\hline I к & $6,6 \pm 0,306$ & $0,71 \pm 0,015$ & $4,89 \pm 0,177$ & 92,96 & 120,9 \\
II & $6,8 \pm 0,389$ & $0,74 \pm 0,027$ & $4,94 \pm 0,247$ & 93,15 & 123,7 \\
III & $7,0 \pm 0,333$ & $0,75 \pm 0,023$ & $5,19 \pm 0,232$ & 94,59 & 126,4 \\
IV & $7,1 \pm 0,407$ & $0,76 \pm 0,016^{*}$ & $5,36 \pm 0,286^{*}$ & 93,42 & 128,8 \\
V & $6,7 \pm 0,396$ & $0,69 \pm 0,015$ & $4,61 \pm 0,232$ & 97,1 & 120,7 \\
\hline
\end{tabular}

Кролематки четвертої дослідної групи мали вірогідну різницю за показником маси одного відлученого кроленяти та маси гнізда у 35-добовому віці $(\mathrm{P}<0,05)$.

Середня жива маса однієї тварини після відлучення була вищою на 40-50 г в 3 і 4-й дослідних групах в порівнянні до першої контрольної і становила 0,75 і 0,76 кг.

Згідно попередніх показників кращими за масою гнізда при відлученні в 35 діб були кролематки знов 4-ї групи - 5,36 кг, що на 0,47 кг вище контролю.

Величина показника збереженості (кількість відлучених кроленят) позитивно корелює 3 показниками багатоплідності, великоплідності, молочності кролематок.

Найвищий відсоток збереження кроленят до відлучення в 35-добовому віці спостерігався в групах 3, 4 та 5-й і знаходився на рівні 94,59; 93,42; 97,1\%. Встановлено, що на збереження гнізда значною мірою вплинула структура раціону кролематок 3 вмістом дерті зерна тритікале сорту Харроза 20, 30 і 40\%.

Показник - індекс відтворюючих якостей кролематок (ІВЯК) виходячи з показників великоплідності, молочності і кількості кроленят при відлученні (в 35 діб) вищим був у кролематок 3 і 4-ї груп з використанням відсотку дерті зерна тритікале сорту Харроза в раціоні 20 і $30 \%$ і становив 126,4 та 128,8 .

Відбулось зростання ІВЯК упродовж досліду 31 по 4 групу 120,9-128,8. За умови однакової поживності всіх раціонів у 5 груп, але після зміни структури кормових компонентів змінювалась динаміка продуктивності сукрільних і лактуючих кролематок. Зростання продуктивності тривало лише до 4 групи, а 3 збільшенням вмісту дерті зерна тритікале сорту Харроза до 40\% (5 група), знизилась, що об'єктивно відобразив показник IВЯК.

\section{Висновки}

На основі проведених досліджень за оптимального використання регіональних кормових інгредієнтів таких, як зерно тритікале сорту Харроза для годівлі помісних сукрільних і лактуючих кролематок отримані позитивні результати.

Максимальні репродуктивні показники забезпечив структурний вміст в раціоні кролематок 30\% дерті зерна тритікале сорту Харроза.

Раціон забезпечив зростання багатоплідності на $8,5 \%$, великоплідності на 5\%, молочності кролематок на $9 \%$, маси гнізда при відлученні в 35 добовому віці на 9,6\%, а комплексного індексу ІВЯК на $6,5 \%$.
Для збільшення виробництва та підвищення продуктивності за інтенсивного виробництва кролятини доцільно використовувати дерть зерна тритікале сорту Харроза для годівлі сукрільних і лактуючих кролематок в структурі раціону на рівні 30\%. Це забезпечить зростання виробництва кролятини в межах $5,0-9,6 \%$ та зниження собівартості на $6,5 \%$. Доцільно проводити подальші детальніші наукові дослідженння щодо вивчення трансформації інших даног кормового фактора за умови промислового вирощування кролів.

\section{References}

Darmohray, L.M. (2010). Experimental justification for the use of nutrients and biologically active substances from food (Galega orientalis (La) different kinds of animals. Manuscript. Doctor of Agricultural Sciences, specialty 06.02.02 - animal nutrition and feed technology. Lviv National University of Veterinary Medicine and Biotechnologies named after S.Z. Gzhytskyj, Lviv, 42.

Darmohray, L.M., \& Shevchenko, M.Ye. (2016). Kormovie drozhzhi - éffektivnyj ystochnik proteina pry vyrashchyvanii krolikov na myaso. "Uchenye zapysky uchrezhdenija obrazovanija "Vitebskaja ordena "Znak Pocheta" hosudarstvennaja akademija veterynarnoj mediciny", 52(1), 113-117 (in Russian).

Darmohray, L.M., \& Luchyn, Y.S. (2016). Alhorytm produktyvnosty hybrydnykh krolykov v zavysymosty ot kolychestva muky solomy pshenychnoy $\mathrm{v}$ kombykorme. "Uchenye zapysky uchrezhdenija obrazovanija "Vitebskaja ordena "Znak Pocheta" hosudarstvennaja akademija veterynarnoj mediciny", 52(2), 128-131 (in Russian).

Darmohray, L.M., \& Luchyn, I.S. (2016). Shlyakhy vyrishennya bilkovoyi problemy za intensyvnoho vyroshchuvannya hibrydnykh kroliv. Naukovi dopovidi NUBiP Ukrayiny, 58, 1-8. http://nd.nubip.edu.ua/ 2016_1/20.pdf (in Ukrainian).

Luchyn, I.S., Korpaniuk, V.D., \& Darmohray, L.M. (2016). Vidtvoryuvalna zdatnist krolematok za vplyvu riznoyi kilkosti boroshna solomy u kombikormi. Biolohiya tvaryn, 18(3), 28-34. doi: 10.15407/animbiol18.03.060.

Darmohray, L.M., Luchyn, I.S., \& Gutyj, B.V. (2017). Influence of feeding management on productive indicators of rabbits for intensive growing technology. Scientific Messenger LNUVMB, 19(79), 38-43. doi: 10.15421/nvlvet7908 (in Ukrainian).

Holushko, V.M., Marusevych, A.H. (1996). Trytykale v kombykormakh dlya otkarmlyvaemoho molodnyaka 
svyney. Izvestija Akademii ahrarnykh nauk Respubliky Belarus, 2, 64-67 (in Russian).

Horkovenko, L., Chykov, A., \& Sakharova-Fetysova, A. (2010). Trytykale v kombykormakh dlya svyney. Zhyvotnovodstvo Rossii, 41-42 (in Russian).

Kyrychenko, V.V., \& Shchypak, H.V. (2005). Sorty ozymykh trytikale. Instytut roslynnytstva im. V.YA. Yur'yeva. Kharkiv, 4 (in Ukrainian).

Luchyn, I.S., \& Vakulenko, I.S. (2004). Method of evaluation of reproductive ability of the krolameth of various genotypes. Scientific-Technical bullet UAAS Institute of animal husbandry, 87, 38-41.

Luchyn, I.S. (2004). Productivity of young rabbits of different genotype combinations depending on the type of feeding. Science. Visn. Lviv nats acad. veterinarian medics them SZ Gzhytsky, 6(2), 211-215.

Maertes, L., Peres, J., Villamide, M., Cervera, C., Gidenne, T., Xiccato, G. (2002). Nutritive value of raw materials for rabbits: EGRAN tables 2002. World rabbits sci., 10(4), 157-166. doi: 10.4995/wrs.2002.488.

Romanov, H.A. (2009). Zhyvotnovodstvu polnoratsyonnye korma (monohrafiya). M. (in Russian).
Symonov, H.A., \& Hurevych, V.Y. (2012). Éffektivnoe zhyvotnovodstvo. HNU Sakhalynskyy NYYSKH Rosselkhozakademyy zhurnal, 8, 34-41 (in Russian).

Tletseruk, Y.R. (2010). Éffektivnost yspolzovanija zerna trytykale i rapsovoho shrota $\mathrm{v}$ racionakh mjasnykh cipljat. Dissertacija. Vladikavkaz (in Russian).

Izmestev, V., Titova, S., Maksimova, R., \& Shmakova, H. (2011). Trytykale v kombikormakh dlya porosyat. Kombikorma, 6, 85-86 (in Russian).

Darmohray, L.M., Sedilo, G.M., \& Gutyj, B.V. (2017). Conceptual framework for the assessment of the nutritional and biological value of the plant Galega orientalis (LAM). Scientific Messenger LNUVMB, 19(79), 9-12. doi: 10.15421/nvlvet7902.

Gutyj, B., Stybel, V., Darmohray, L., Lavryshyn, Y., Turko, I., Hachak, Y., Shcherbatyy, A., Bushueva, I., Parchenko, V., Kaplaushenko, A., \& Krushelnytska, O. (2017). Prooxidant-antioxidant balance in the organism of bulls (young cattle) after using cadmium load. Ukrainian Journal of Ecology, 7(4), 589-596. doi: 10.15421/2017_165. 